\title{
Women's Legal Voice: Language, Power, and Gender Performativity in Late Chosŏn Korea
}

\section{JISOO M. KIM}

Based on a neo-Confucian vision that the monarch's mandate relied on listening to his people's grievances, the Chosŏn state (1392-1910) empowered subjects regardless of gender or status to address grievances to the sovereign that had not been rectified in lower courts. Contrary to the preconceived notion that women of the Chosonn were silent subjects outside their domestic boundary, their petitioning activity shows that women, irrespective of their status, had the same legal capacity as their male counterparts to appeal grievances at local and capital levels. This article focuses on women's petitions and their linguistic practices to show how their petitioning activity complicated the gender dynamics of Confucian society. While the gender hierarchy was reinforced through women's narrative strategy as they appropriated the discourse of domesticity, I posit that women as legal agents were regendering legal identity by constructing a sense of personhood via their petitioning practice. Through articulating their gendered narratives, women struggled to defend not only themselves and their own sense of morality but also their entire family.

$\mathrm{I}$ THE SECOND MONTH of 1786, Sodok, a female slave and the wife of Pak Ch'adol, presented a written petition to King Chŏngjo (r. 1776-1800). She stated in her petition that her husband, who was a slave of the Board of Taxation (Hojo 户曹), died in 1776, and thereafter she was unfairly levied a tax of her husband's. She thus pleaded to be relieved from the tax burden. Chŏngjo considered her grievance legitimate and ordered that her request be granted (Ilsŏngnok, Chŏngjo, 1786/2/26). ${ }^{1}$

This short anecdote is just one among a multitude of historical records preserved in legal archives. There are nearly 600 records of women's petitions from the Chosŏn, including at both local and capital levels, and most petitions are from the eighteenth and nineteenth centuries. Approximately 25 percent of the 600 petitions are from county and provincial levels; these petitions exist in original form and are extremely rich in anecdotes. ${ }^{2}$ According to Han Sang-gwŏn's (1996, iii) study, there were 4,427 petitions

Jisoo M. Kim (jsk10@gwu.edu) is Korea Foundation Assistant Professor of History, International Affairs, and East Asian Languages and Literatures at the George Washington University.

${ }^{1}$ All references to lunar calendar dates in the text and notes appear as year/month/day (e.g., 1786/ 2/26).

${ }^{2}$ Local-level petitions can be located in the Komunsŏ 古文書 (Old documents) and Komunsŏ chipsŏng 古文書 集成 (Compilation volume of the Old documents) compiled by the Kyujanggak Archive of Seoul National University and the Academy of Korean Studies, respectively. Unlike petitions submitted at local courts, most of the petitions presented to the king are recorded in official documents such as the Sillok 實錄 (Veritable records), Ilsŏngnok 日省錄 (Records of daily reflections), Sŭngjŏngwŏn ilgi 承政院日記 (Daily record of the Royal Secretariat), Pibyŏnsa 
submitted to the king between 1776 and 1800. This number excludes those that were submitted to county and provincial courts. Compared to men's petitions extant from the late Chosonn period, the number of women's petitions is relatively small, as their grievances were limited to individual and family grievances. However, this does not mean that their petitioning activity was less significant when considering the procedures these women went through in petitioning the state. Furthermore, women's act of petitioning along with their male counterparts greatly influenced the shaping of the legal culture of the late Chosón period. Based on 151 women's petitions I found that were submitted at county and provincial courts between the mid-seventeenth and the nineteenth century, I focus on women's narrative and linguistic practices to demonstrate how female subjects appropriated the "discourse of domesticity" and the Confucian rhetoric of female virtue to seek their interests.

Contrary to the common perception that women of the Chosonn were silent subjects outside their domestic boundary, their petitioning activity shows that women, irrespective of their status, had the same legal capacity as their male counterparts to appeal grievances. As the short opening anecdote shows, even female slaves were recognized as legal subjects and authorized to voice grievances to the ultimate point of justice. By "legal subjects," I mean those who had the capacity to engage in legal actions, such as filing petitions or suits, entering into contracts, buying or selling, borrowing or lending, and making bequests. Among different kinds of legal activities women engaged in, the primary focus of this paper is on the practice of women's petitioning. ${ }^{3}$

The Chosŏn state installed the “petition drum” (sinmun'go 申聞鼓) during T'aejong's reign (r. 1400-18) in 1401 based on a neo-Confucian vision that the monarch's mandate relied on listening to his people regardless of one's gender or status. Although subjects had been authorized to petition the government during the Koryŏ dynasty (918-1392), the legal channel to voice concerns directly to the sovereign was not instituted until the Chosŏn dynasty was established. ${ }^{4}$ The drum was installed in front of the State Tribu-


had not been rectified in lower courts. With the advent of the petition drum, it was possible for even the voices of the lowest subjects, such as female slaves, to reach the apex of the power structure. The underlying meaning of every subject's having the legal capacity

tŭngnok 備邊司謄淥 (Records of the Border Defense Command), and Simnirok 審理錄 (Records of simni [hearings]). Many of the records in these different sources overlap. For example, a number of women's petitions recorded in the Simnirok can be traced in the Sillok as well as the Ilsŏngnok. In Han Sang-gwŏn's meticulous research on petitions of the late Chosŏn, there are detailed statistics based on the Ilsongnok's records during the reign of Chŏngjo. Han Sang-gwŏn (1996) shows that there are 108 petitions of elite women and 310 petitions of commoner women but does not mention the lowborn. Further, his statistics lack women's petitions from other periods as well as from other regions. Although he provides raw numbers of women's petitions, he does not analyze them, as they are not the focus of his study: men's petitions are. My study not only complements his data but also fills in the gap of voices from the other half of the population. For statistics on women's petitions, see Han Sang-gwŏn (1996, 110-11 and 120-21).

${ }^{3}$ In Komunsŏ, it is possible to find a variety of legal sources, such as petitions, contracts, wills, property documents, and officially endorsed documents (iban 立案).

${ }^{4}$ For a discussion of the transition from the Koryŏ to the Chosŏn dynasty, see Duncan (2000) and Deuchler (1992, 29-87). 
to petition is that petitioning enabled even the most subordinate agents, such as female slaves, to make a direct relationship with the authorities, one that provided an opportunity for communication between the ruler and those ruled. ${ }^{5}$

There is no doubt that women's legal position in the Chosŏn was inferior to men's, especially when taking into consideration women's inability to take the civil service examination, unequal share of inheritances in the latter part of the dynasty, and lack of position in ritual heirship. However, one needs to pay special attention to the state's recognition of women as legal subjects and the power of the legal capacity they exercised when entering courts to file complaints against their family members, relatives, neighbors, and even magistrates. In such a highly stratified and gender-segregated society as the Chosŏn, it is striking to find that the hierarchies were neutralized to a certain degree as people of different genders and statuses all interacted in courts as legal subjects.

Based on women's recognition as legal subjects, it is of course naïve to assume that discrimination did not exist in the realm of law. Inequalities in Confucian law were evident when subjects became the objects of punishment, as punishment was unequally determined based upon one's status, rank, privilege, gender, and age. Also, Confucian law prohibited son, wife, and slave to file a complaint against father, husband, and master, respectively. Nevertheless, what I mean by the neutrality of gender or status here is that every person was recognized as a legal subject when it came to the right to redress a grievance through petitioning.

The juridical domain was often a contestation ground of social conflict between privileged and underprivileged, aristocrat yangban versus commoner, affluent commoner versus destitute commoner, ex-owner versus manumitted slave, widow versus male relative, and public official versus private individual. The legal space was one of the few social sites where women, regardless of status, were empowered to publicly challenge men of even higher status. Subordinate agents could make complaints against powerful subjects when the privileges they were allowed to enjoy within their status had been infringed upon. Conversely, while the petitioning practice reinforced the social hierarchy by requiring subjects to execute duties within their status boundary, it concurrently allowed them to seek protection of their position enjoyed within that boundary. In a highly stratified and gender-segregated society such as the Chosŏn, the puzzling question is how it was possible for the state to recognize every subject regardless of gender or status as an independent legal subject. ${ }^{6}$

\footnotetext{
${ }^{5}$ During the Chosón, there was a small group of governing aristocrats at the top of the society known as the yangban 兩班. This group enjoyed most of the socioeconomic privileges in the Chosŏn. Due to class instability in the late Chosŏn, yangban no longer immediately signified the ruling class, whereas sadaebu 土大夫 did refer specifically to the ruling group. There was another small group known as the "middle people" (chungin 中人) that consisted mostly of technical specialists and functionaries. Under the middle class, there were the commoners, most of whom were peasants known as yangin 良人 or sangmin 常民. These people made up the majority of the population and carried most of the burden of taxation, military service, and corvée labor. Lastly, the lowborn, known as ch'ŏnmin 賤民, were mostly slaves but also included those with debased occupations, such as butchers, tanners, shamans, and female entertainers.

${ }^{6}$ Previous studies on the topic of petitioning have examined the establishment of the petition drum and its practice but have not questioned how people of different genders and statuses were empowered to utilize the system (Han Sang-gwŏn 1996; Han U-gŭn 1956, 357-408; Kim Kyŏng-suk 2005).
} 
My aim is not to answer this puzzling question here not only due to limited space but also because it is discussed elsewhere in depth. ${ }^{7}$ I find it sufficient in this study to introduce women's petitions and underline their voice as legal agents in the late Chosŏn. In doing so, my focus is to analyze women's linguistic practices manifested in petitions to show how their patterns of behavior shaped, molded, and formed gendered legal practice. By examining women's petitions addressed to the state, I show how their linguistic practices, regardless of their different social statuses, were unified to meet the demands of the linguistic market in the realm of law. In doing so, I demonstrate how both elite and nonelite women utilized legal narratives based on the Confucian language that adhered to the official representation of gendered images. Although women were conferred with the same legal capacity as men, their concerns were limited to personal and domestic affairs, unlike men, who also appealed on public grievances. The practice of petitioning was performed in a culturally restricted setting that was regulated by legal codes and bound within preexisting norms. By carrying gender norms to the legal space, the gender hierarchy was reinforced through women's narrative strategy as they appropriated the "discourse of domesticity." However, women as legal agents were regendering legal identity by constructing a sense of personhood via their petitioning activity. Through articulating their gendered narratives, women struggled to defend not only themselves and their own sense of morality but also their entire family. ${ }^{8}$

Borrowing Judith Butler's (2007) usage of gender performativity, I demonstrate how female petitioners possessed a keen gender consciousness and how they constructed their identity through a particular vocabulary of gender behavior. Performativity of gender, according to Butler (1999, 163-80), is a stylized repetition of acts, imitation, or miming of hegemonic gender and very often the repetition of oppressive gender norms. Engaging with Butler's reflections on how a woman must negotiate a position for her identity in relation to established prescriptive norms, I consider how women's gender identity was deeply related to their linguistic usage of Confucian rhetoric in their representations of grievance. Through their repetition of petitioning acts, women performed gendered legal identity by appropriating Confucian language of female virtue and narrative of pity. While using such a narrative strategy to win the favor of ruling authorities, women simultaneously sought their interests and negotiated their positions. ${ }^{9}$

${ }^{7}$ The discussion of the state's recognition of every subject regardless of gender or status as legal subjects and the two petition cases used for this article appear in chapters 2 and 3 of my book, The Emotions of Justice: Gender, Status, and Legal Performance in Chosŏn Korea, forthcoming in 2015 from the University of Washington Press.

${ }^{8}$ Susan Hirsch, in her study of legal processes and gendered legal discourses in Swahili Kenya, eloquently shows how women worked within the confines of Islamic law while they utilized the social conventions of female speech and behaviors to shape rules in their favor. In court, women represented themselves as obedient and persevering wives using the conventional gendered speech but simultaneously spoke of husbands' shortcomings (Hirsch 1998). I was inspired by Hirsch's book when formulating ideas related to women's legal activities in the Chosŏn.

${ }^{9}$ In her examination of criminal records and female suicide, Jungwon Kim $(2007,2014)$ claims that women negotiated their positions based on their socioeconomic status in their legal testimonies. My examination of petition sources corroborates this claim in that the kind of grievances women addressed differed based on their socioeconomic status. My study further shows how women articulated their narrative to seek their interests using the Confucian rhetoric of female virtue and appropriated their weaker position in the society to achieve their ends. 
When comparing women's legal position in Chosŏn Korea with that of other contemporary cultures, such as China, Europe, and the Middle East, one finds interesting similarities and differences across regions. Despite the geographic proximity of China and Korea, women of the Chosŏn shared more similarities with those in the Middle East in terms of their recognition as legal subjects. Islamic law made little distinction between women and men when it came to their legal capacity. Women in Islamic cultures were authorized to engage in legal transactions without depending on men's guardianship. While a husband had the right to control his wife's sexuality, he did not have the right to control her property. Women had the right to manage or dispose of all kinds of property that they acquired, even after marriage (Tucker 2008, 187-99). Women in the Middle East were also empowered to petition in person to seek royal justice (Zarinfraf-Shahr 1997).

In the case of China, a woman had to employ a proxy filer, often her son or another male family member. Proxy filers were legally required to be the petitioner's co-resident male relatives. In 1873, the Qing state further restricted women's participation in legal activity by requiring that an adult son file the litigation. Only in the absence of a son was a woman allowed to file through another proxy. A woman would be punished if she filed in person. However, this requirement was waived if the woman had no male relatives. One similarity between women in China and the Chosŏn was that a woman was able to file a petition on behalf of her husband when he was incapable of bringing charges himself because he was either a detained suspect or an imprisoned convict. Mark Allee (1994, 148-74) suggests that requiring women to employ proxy filers may have been an artifact of cultural norms that secluded women.

In many jurisdictions of Europe until the 1800s, a married woman's legal rights merged with those of her husband when married. While single women and widows had the right to own property, draft wills, and appear in court on their own behalf, married women were restricted in their legal role and prevented from obtaining legal independence. In Florence during the Renaissance period, the law regulated that women be represented by an adult male, a so-called male guardian (Kuehn 1991, 212-37). In the extreme case of England, under the doctrine of coverture, a married woman was entirely subsumed within the legal identity of her husband and was not able to sue, make contracts, or go to court without her husband's permission (Blaine 2002, 58). The state perceived women's petitions with derision in the seventeenth century and further vilified women's presence in public when voicing the grievances of their imprisoned husbands (Orchard 2002, 12-13). However, Gregory A. Mark (1998, 2183-87) suggests that in prerevolutionary America women's petitions were not rejected due to their status as femme covert. Numerous studies on women's legal status in Western scholarship show how women were able to exercise power and gain economic independence by appropriating loopholes in law codes.

In sum, Chosŏn women had much commonality with contemporary Middle Eastern women in that there was little distinction between genders when exercising legal capacity. However, while Chinese women had more parallels with women in England in terms of being represented by male guardians, Chinese women and Chosŏn women were both able to petition for husbands who were imprisoned, although English women were derided for speaking in public for husbands. From a comparative perspective, it is crucial to further explore the implication of women's legal capacity that was not subjected 
to men in patriarchal Chosŏn society prior to the introduction of the modern Western legal system at the turn of the twentieth century.

\section{The Confucianization of Language in Legal Space}

When the Chosŏn dynasty was established in 1392 and adopted neo-Confucianism as its state ideology, the society underwent drastic changes as the state envisioned a normative Confucian society by implementing the Confucian model of patriarchy and patrilineality. This Confucianization of society was a process of change accomplished through a dynamic interaction between Confucian norms and Korean indigenous practices (Deuchler 1992; Haboush 1991). Although certain elements of Confucianism were in place before the Chosonn, it was with the advent of this dynasty that neo-Confucianism was adopted as official ideology and was accompanied by a reorganization of the indigenous family structure. For example, during the Koryŏ dynasty, sons and daughters were treated as equal members of the family, whether married or unmarried, and received equal shares of inheritances. The marriage practice was uxorilocal, and women remained active in their natal homes. Remarriage was not a problem, and women divorced when necessary. The society was bilateral, which allowed daughters' children to succeed the family line.

In the Chosŏn, these practices shifted according to the Confucian patriarchal and patrilineal systems. As ancestral rites were introduced, the ritual duties were given to sons only; ${ }^{10}$ daughters were no longer treated as equal members of the family and thus received lesser shares of inheritances (Deuchler 1992; Peterson 1996); the marriage practice shifted to virilocal, and women left their natal homes to serve their husbands' families; remarriage became socially stigmatized, and restrictions on remarriage were imposed on elite women; clear demarcations were drawn between legal wife and concubine, creating hierarchy and tension between them; and the society shifted from bilateral to patrilineal, such that only through sons could the family line be succeeded.

Conventional wisdom on the Confucianization of Korea suggests that these changes occurred through a gradual process and only became evident by the mid-seventeenth century (Ch'oe 1966; Deuchler 1992; Haboush 1991; Peterson 1996). The changes brought adverse effects on women, especially the elite, as they were deprived of ritual, economic, and social privileges. Although one cannot deny the negative effects Confucianization had on women, it must be emphasized that they were not deprived of legal capacity even as they lost other privileges toward the late Chosŏn.

Recent studies on women of the Chosŏn have explored the lives of nonelite women and have demonstrated how these women led much more diverse lives compared to elite women. Their lives show a much more complex picture according to their socioeconomic situations, and they were less bound by official representation of gender norms (Chŏng 2001; Jisoo M. Kim 2010b; Jungwon Kim 2007; Kim Kyŏng-suk 2005; Kim Young-min and Pettid 2011). These recent studies are significant in that they use a variety of

\footnotetext{
${ }^{10}$ In the early years of the Chosonn, daughters shared ritual duties and continued to receive equal shares of inheritance with sons. However, these practices gradually changed as the society Confucianized by the mid-seventeenth century (Deuchler 1992).
} 
sources to examine the lives of nonelite women, who had been mostly invisible throughout Korean history. The results of these recent studies raise critical questions about the late Chosŏn society: To what extent were the lower strata Confucianized? If sexual and marriage practices of nonelites were not greatly influenced by the Confucianization process, then what aspects of Confucianization were reflected in the lives of nonelites, who were the majority of the population? In order to answer these questions, it is necessary to break down the Confucianization process into various components and explore its multilayered representation in the context of a gendered and stratified society.

As far as women's linguistic practices in petitions are concerned, they were Confucianized in the sense that female subjects relied on the rhetoric of Confucian virtue despite their differences in social reality. For example, as women's concerns revolved around domestic affairs, it is very common to find women's narratives emphasizing their marital fidelity and filial piety. ${ }^{11}$ Although nonelite women had different lives than elites in many ways, they also knew how to use the Confucian language when engaging in dialogue with neo-Confucian bureaucrats. According to Pierre Bourdieu, a unified linguistic market dominated by an official language is created in the process of state formation, and this state language becomes the theoretical norm that measures linguistic practices. The political process of unification is then determined by a set of speaking subjects who are led to adopt the official language, which then reinforces the authority by integrating the subjects into a single linguistic community (Bourdieu 1994, 45-46). When the linguistic practice in the juridical domain of the Chosŏn is taken into consideration, one can see that legal subjects adopted the official Confucian language, and the state succeeded in creating a "single linguistic community." This not only enhanced the power of the authority but also empowered female subjects as they demanded that the state listen and redress the grievances of weaker subjects to manifest its supposed benevolence of Confucian governance.

\section{Women's Choice of Language}

When petitioning to redress a grievance, petitioners initially turned to county magistrates for rectification. If the grievance was not redressed at the county level, they then appealed to the provincial office. If it still was not redressed, then appellants went to the capital and appealed to the Office of the Inspector General (Sahŏnbu 司憲府). If the grievance was not fully redressed after all these judicial remedies were exhausted, then petitioners appealed directly to the king as a last resort by beating the petition drum installed in front of the State Tribunal (Kyŏngguk taejŏn 1978, 473-74).

In petitioning both local authorities and the king, women submitted written petitions in two different languages, that is, classical Chinese and vernacular Korean. This was one of the primary differences between women's and men's petitions. Since the invention of the Korean script (Ŏnmun 颜文) in 1446, the Chosŏn dynasty had maintained a diglossic culture in the literary space. While classical Chinese dominated the writings of the public realm, women mostly used vernacular Korean in the private realm. Men also used

\footnotetext{
${ }^{11}$ For a discussion of elite women's petitioning activity during the late Chosŏn, see Jisoo M. Kim (2009, 2010a).
} 
vernacular Korean when exchanging letters with female members of their family. Because classical Chinese was perceived as men's language and was also difficult to learn, women were educated with vernacular Korean, which was much easier to acquire. Although the two representative volumes of Chosŏn legal codes, the Kyŏngguk taejŏn 經國大典 (Administrative Great Code) and the Sok taejon 續大典 (Continuation of the Great Code), do not explicitly stipulate the written language for petitions, it was taken for granted that petitions should be submitted in classical Chinese, as were all other public documents.

Although the state conferred the legal capacity to petition to all subjects, women, as well as men of the lower social strata, who were mostly illiterate in classical Chinese, were unable to draft petitions themselves. Thus, it was necessary for them to rely on scriveners or male family members who were versed in classical Chinese. ${ }^{12}$ Despite this limitation that women faced, what is intriguing is that they actively appropriated their knowledge and submitted petitions in vernacular Korean instead, thereby challenging the public literary space. ${ }^{13}$ The earliest Korean script petition I found was submitted in 1509, during the reign of King Chungjong, by a daughter of the royal clan whose name was Ch'ollbi. She appealed to be exempted from being demoted to a private slave. The court officials argued that her crime was unpardonable, and they further criticized her for writing the petition in the Korean script, which digressed from the proper form (Chungjong sillok 1509/4/16 and 1509/9/11). ${ }^{14}$ Nevertheless, the king granted her immunity from being sent as a slave to a house of a meritorious subject (Chungjong sillok 1510/12/12). It was during the Kwanghae-gun period (r. 1608-23) that government officials discussed seriously whether Korean script petitions should be accepted. ${ }^{15}$ Although the state made no effort to legalize this matter, it eventually acknowledged such petitions because rejecting them countered the state's intention of redressing grievances. ${ }^{16}$

Based on 151 petitions submitted at county and provincial courts during the late Chosŏn, twenty-five were drafted in vernacular Korean and the rest in classical Chinese. Of the twenty-five vernacular Korean petitions, eleven were presented by elite yangban women and fourteen by commoner women. (For an example of a vernacular Korean petition concerning a land dispute submitted by a commoner woman, see figure 1.) Although the numbers show that women used classical Chinese in petitions more often than vernacular Korean, what is vital about the petitions written in the

\footnotetext{
${ }^{12}$ For details on scriveners, see Pak (1996, 337).

${ }^{13}$ This public literary space had also been challenged by queen dowagers who wrote royal instructions in the vernacular Korean script. However, writing royal instructions at court was limited to women of the royal family, whereas drafting petitions applied to women of all social statuses including aristocrats, commoners, and the lowborn. For details on the politics of language in Choson Korea, see Haboush (2002).

${ }^{14}$ The record does not mention the crime she had committed.

${ }^{15}$ The two versions of the Kwanghae-gun ilgi both record the discussion of whether the Korean script petition submitted by Madam Kim, wife of Yi Hongno (1560-1610), should be accepted. See Kwanghae-gun ilgi, 1610/5/5, 1610/5/10, and 1610/5/16. Also cited in Haboush (2002, 250).

${ }^{16}$ For example, Madam Yi, wife of the private scholar (yuhak 幼學) Cho Chinsŏng, submitted a Korean script petition, but the state did not question its written language (Ilsŏngnok, Chŏngjo, 1787/4/4).
} 


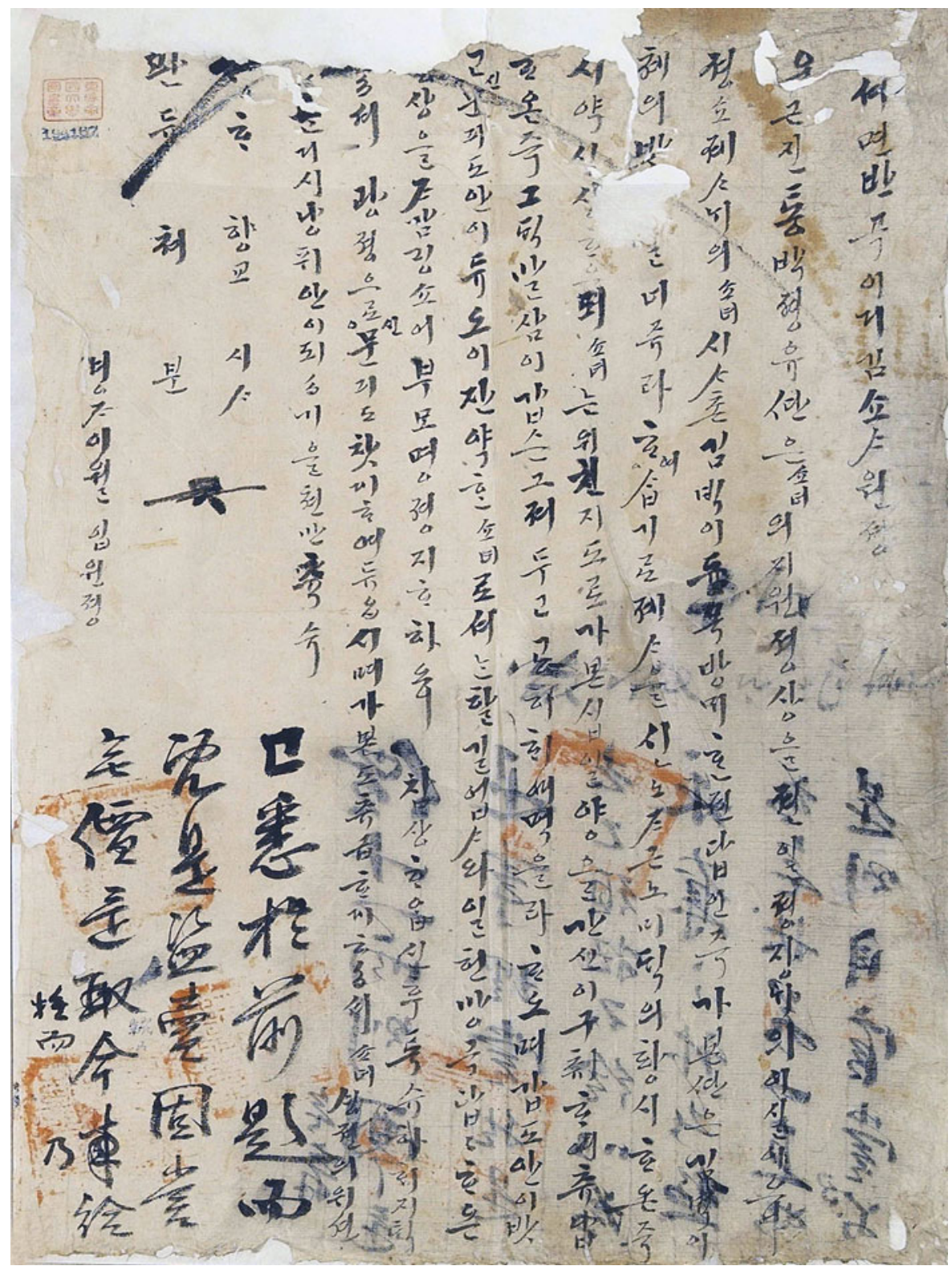

Figure 1. A commoner woman Kim's vernacular petition (land dispute). Komunsŏ 194167. Courtesy of Kyujanggak Archives, Seoul National University.

Korean script is that they were officially recognized by local governments despite the fact that such petitions were illegal.

Although the state continued to take issue with women's Korean script petitions when presented to the king, the petitions submitted at county and provincial levels show that women succeeded in receiving official red seals with the language they employed in domestic space. Kim Kyŏng-suk (2005, 97) suggests that female petitioners must have relied on scriveners or male kin even when they drafted the petitions in 
vernacular Korean. Whether or not a woman literally wrote the petition herself is not my point here. What is noteworthy is their participation in the process of drafting the petitions and the fact that it was female subjects rather than their male counterparts who decided to write in the Korean script, unacceptable in the public realm. If women relied entirely on men's assistance, it hardly would have been likely for vernacular Korean petitions to appear in court. Therefore, I contend that it was a woman's will to draft a petition in the language she was versed in to seek her own interests. This was a way of identifying herself and representing femaleness through the very performance of public writing. By capitalizing on the capacity to petition, women challenged the literary space that was dominated by classical Chinese and extended the usage of vernacular Korean to the legally sanctioned public realm.

It was not uncommon for women to strategically use both languages when they submitted several petitions. For example, Madam Cho, who was involved in a property dispute, submitted four petitions in total; the first petition, submitted in the ninth month of 1816, was written in classical Chinese, but the other three petitions, submitted in the following month, were all drafted in vernacular Korean. ${ }^{17}$ When petitions written in classical Chinese and vernacular Korean are compared, there is not much difference in the content, which makes it difficult to discern the petitioner's intention behind using the two different languages. The petitions do not provide even a hint concerning the language issue. However, it is not far-fetched to assume that it was female subjects themselves who made the language choice.

For instance, Madam Yi's vernacular Korean petition shows that she actually drafted the petition herself. In the will she left for her children, she emphasized that she was writing in vernacular Korean with her own handwriting to show that she was the person drafting the will. Similarly, she had also drafted the petition, which shared the content of the will, in vernacular Korean. ${ }^{18}$ Madam Yi submitted the petition in the language she was accustomed to based on her own discretion. As early as 1509, women began to utilize vernacular Korean to communicate with authorities at the capital level. However, Korean script petitions, although not entirely rejected, continued to be criticized when presented to the king. In stark contrast, Korean script petitions from the late Chosonn show that they were officially recognized at county and provincial courts. This point is vital because it reflects how women, as moral agents, actively capitalized on their legal capacity to petition. The fact that it is rare to find men's Korean script petitions prior to the late nineteenth century further substantiates how it was women who successfully introduced vernacular Korean to the petitioning process. It was possible, at least at the local level, to reflect diglossic culture in the public literary space, previously dominated by classical Chinese, through the performance of women's legal writing.

Madam Yi's petition, which was drafted in the mid-1650s, was about a legal dispute with Sŏgu, who was the secondary son of her stepson. ${ }^{19}$ She filed a complaint to punish

\footnotetext{
${ }^{17}$ Hong Ŭn-jin (1998) first introduced Madam Cho's vernacular Korean script petition in her article.

${ }^{18}$ Madam Yi’s petition and will can be found in Kim Yong-kyŏng (2001). The aim of the journal, Munhŏn kwa haesŏk (Sources and interpretation), is to introduce newly excavated sources intact with scholarly analysis. Madam Yis original petition and will are both introduced in this journal.
} 
him for attempting to usurp the lineal heir's position, along with other crimes he had committed. Madam Yi was the second wife of Hwang Yŏil (1560-1608), who was a highranking scholar-official during the reign of King Sŏnjo (r. 1567-1608). Hwang had a son named Sŭngji with his first wife and then had four sons with Madam Yi, in the order of Chungmin, Chunghŏn, Chungsun, and Chungwŏn. Sŭngji, who was the lineal heir, failed to produce a son with his primary wife and thus needed to adopt a son in order to maintain the patriline. Sŭngji’s father, before his death, had ordered Sŭngji to adopt one of his half-brothers' sons. Following this wish, Sŭngji decided to adopt Sŏngnae, Chunghŏn’s son. However, Sŭngji's untimely death led Sŏgu to covet Sŏngnae’s position and conspire to replace him with Chungmin's son. Sŏgu claimed that it was illegitimate to adopt Chunghŏn's son while Chungmin's son, who was the eldest in the line, was alive.

Madam Yi regarded Sŏgu's action as a challenge and petitioned the king in order to report his attempt to go against his father's will in selecting the heir of the family. ${ }^{20}$ After reviewing Madam Yi's petition, the state banished Sŏgu to Paengnyŏng Island for three years. Madam Yi, still concerned that he would continue to cause trouble, decided to write a will to confirm Sŏngnae's position as lineal heir. On the twentieth day of the third month in 1651, she drafted a will stating that if Sŏgu and Chungmin fabricated the document of family succession and attempted to displace Sŏngnae, then other family members should take her testimony as evidence to report to the government, asking to punish them. She ended the will by stating that she had drafted it herself in vernacular Korean to show her determination to maintain family order. ${ }^{21}$

On the eighth day of the first month in 1656, Madam Yi drafted a petition to submit to the magistrate of her county. Unlike other petition documents in the records, this petition lacks an official's written judgment, which implies that it was either never submitted to the county office or is a copy of the version that had been submitted. Whatever the case, Madam Yi wrote the petition in vernacular Korean and intended to have Sŏgu punished for a second time. She addressed how Sŏgu had continued to misbehave even after his release from Paengnyŏng Island. Sŏgu stole Madam Yi’s family document and bribed powerful officials at the central bureaucracy to gain their support. Moreover, he tore up the letter she sent to him asking him to return the document he stole. In her petition, she stated:

I am extremely afraid to report to Your Honor, who is in such a high position. I am old and sick but I write this petition without any shame or fear because my rage has soared up to the sky.... When he [Sŏgu] read my note, he tore it into pieces and humiliated me in every possible way and never showed up. How on earth can he be so insolent and vicious! ... I first pitied him because he was, in one way or another, one of my family members. Because I pitied him, I am humiliated by him today.... Please consider the following six crimes he committed and punish him strictly based on the laws: the crime of humiliating

\footnotetext{
${ }^{19}$ For a discussion of secondary sons and their inferior status in the Chosŏn, see Deuchler (1988/ 1989).

${ }^{20}$ The petition sent to the king no longer exists but is mentioned in Madam Yi's will, as is the petition written in 1656.

${ }^{21}$ The will was first introduced in Yi (1982). It was reintroduced in Kim Yong-kyŏng (2001, 79-82).
} 
the legitimate grandmother of the family, the crime of betraying the masterslave relationship, the crime of attempting to succeed his father's lineage by following the father's bloodline instead of his mother's, the crime of stealing the family document and selling it, the crime of not participating in the ancestral rituals for his father, and the crime of abandoning his mother. Please consider each of these six points and apply all the existing laws to make him realize the importance of state law (gukpŏp 國法). By doing so, please protect this aged and weak widow. I end here as I am afraid to write any further. (Kim Yong-kyŏng $2001,82-87)^{22}$

Although Madam Yis grievance stemmed from Sŏgu's attempt to deprive Sŏngnae of his rightful position, the tone of her petition resonates more of her rage provoked by humiliation or frustration. Madam Yi was determined to punish Sŏgu for disrespecting the senior member of the household and challenging her authority. It was possible for Madam Yi to make a complaint against Soggu because he was a son of a concubine. She also noted her relationship with Sŏgu as master-slave: Sŏgu's mother was previously Madam Yis slave. Madam Yi allowed Sŭngji to take her slave as a concubine when he had asked for permission. According to the matrilfilial succession law (chongmopóp 從母法), the status of offspring was defined by the mother's status. If Sŏgu's mother bore him without having gained commoner status, then in principle his status would have been slave. Because his master was the grandmother and senior member of the family, it was possible for him to live a life that distinguished him from ordinary slaves.

In her vernacular Korean petition, Madam Yi opened and ended her statement by relying on a narrative of pity, which is very common in women's petitions, emphasizing her age and illness. As a widow and senior member of her household, she appealed to the magistrate regarding how Sŏgu, a secondary son, had dared challenge her authority and thereby dishonored her. When writing her petition, she utilized the narrative of pity by underlining her position as a feeble widow but simultaneously claimed her authority as head of the household. While relying on the narrative of pity, she urged the magistrate to punish Sŏgu, stating that the laws should be applied appropriately to restore her honor and protect her interests. In women's petitions of the Chosŏn, it is not difficult to find instances where female subjects rely on the narrative of pity emphasizing their subordinate position as women but concurrently use strong statements to seek their interests.

The next case, which is about a gravesite dispute written in classical Chinese, shows how a nonelite woman similarly used a narrative of pity to achieve her ends. Although it is likely that elite women, as shown in Madam Yi's case, wrote vernacular petitions by themselves, most female petitioners had to rely on professional scriveners or men in their family or community to draft their petitions either in classical Chinese or vernacular Korean. Some scholars thus consider that women's voices and their role were limited in the petitioning process, as they relied on men in composing their petitions (Kim Kyŏng-suk 2005, 97). When viewed this way, it is not only female petitioners whose role was limited, as the same could be said of illiterate nonelite men. Even if those who wrote the petitions were not the petitioners themselves, it cannot be denied that

${ }^{22}$ All the translation of original sources in this article is mine. 
both illiterate female and male petitioners shaped their own narratives. Whoever wrote the petitions could not have put pen to paper without the stories told by the petitioners. However, scriveners may have employed narrative skills to better articulate grievances when producing written petitions. ${ }^{23}$ Unfortunately, we have no access to original stories told by female petitioners to scriveners. It is difficult to assess to what extent the stories presented in petitions followed the petitioners' original stories. However, it is clear that the role of drafters was not to invent new stories but to effectively package the grievances of petitioners to win favor. ${ }^{24}$

When taking into consideration that even men relied on professional male scriveners, there is not much point in discussing whether it was women's voices in their written petitions. From a gender perspective, what is more noteworthy in the context of Confucian society is the multilayered process of storytelling in petitioning and how the process eventually generated gendered legal narrative. In other words, instead of focusing on whether women ipso facto wrote their petitions, it is more fruitful to discuss the gendered narrative that was produced as a result of multiple actors involved in the storytelling. If petitioners told their grievances, then it was the scriveners' task to "craft" those stories to amplify the narrative of grievance..$^{25}$ The process of producing written petitions entailed multiple layers of storytelling, which ultimately generated a bifurcated, gendered legal narrative that conformed to the conventional norms.

Gravesites were an issue that women of different statuses commonly petitioned, along with issues of property. ${ }^{26} \mathrm{~A}$ gravesite dispute, known as sansong 山訟 in Korean, was about the usage of a mountainside or gravesite. Along with suits involving land and slaves, this was considered one of the three major types of lawsuits in the late Chosŏn period. Unlike land and slave litigations, gravesite disputes were rarely witnessed in the earlier part of the dynasty. However, they gradually increased as the society Confucianized toward the later Chosonn and became the most frequently filed type of lawsuit, especially in the eighteenth and nineteenth centuries.

Scholars who have examined this issue have claimed that it reflected broader socioeconomic problems of the late Chosŏn period and was not merely about land used for graves. One of the reasons people increasingly engaged in this type of dispute was that the state lacked the ability to devise an appropriate policy regarding the usage of mountains according to its changing practices. Although mountains were treated as public property, subjects appropriated various means to possess them. For instance, people demarcated the boundary surrounding an ancestor's gravesite and inhibited woodsmen or others from trespassing to gather firewood or cut trees. As the gravesite zone passed down three or four generations, it gradually came to be possessed by private individuals. By the end of the Chosonn, contracts show that different zones of mountains were bought

\footnotetext{
${ }^{23}$ Unfortunately, the role of scriveners is almost invisible from the extant sources. However, it is possible to find scant writings about them in literary works. For the role of scriveners in the Chosŏn, see Pak $(1974,257)$ and Han Sang-gwŏn (2008, 284-89).

${ }^{24}$ For the significant role of scriveners and the crafting of plaints in late imperial China, see Macauley (1998) and Karasawa (2007).

${ }^{25}$ For a discussion of reading "fictional" elements in pardon letters in sixteenth-century France, see Davis (1987).

${ }^{26}$ For a discussion of elite women's property dispute, see Jisoo M. Kim (2013).
} 
and sold like any other private property. Because the state neither punished nor officially approved the possession of mountain areas by private individuals, the number of gravesite disputes continually increased and became one of the major social phenomena in the late Chosŏn (Chŏn 1996, 1998; Kim Sŏn-kyŏng 1993).

In addition to understanding the gravesite dispute as a conflict over possession, one can also see it as a conflict stemming from the consolidation of the neo-Confucian patrilineal system. Although this type of dispute was initially considered to be a conflict only among elite aristocrats, it gradually spread to even the lowborn by the late eighteenth century (Kim Kyŏng-suk 2002). The most common type of gravesite dispute occurred when someone furtively buried a body in another's ancestor's gravesite in order to dispossess them of their site. The following case, that of commoner woman Chŏng, manifests such a dispute and also reflects the typical strategy defenders used when they were sued. Defenders purposefully delayed exhuming a body day after day in order to displace the gravesite zone through the presence of the body.

In the third month of the year sinhae 辛亥, a commoner woman with the surname Chŏng, wife of Kim Manbok and resident of Kongju County of Ch'ungch'ŏng Province, submitted a petition written in classical Chinese to the magistrate of Kŭmsan County of Chŏlla Province, concerning a gravesite dispute. ${ }^{27}$ Prior to this petition, she had initially appealed to the predecessor of the current magistrate in a complaint against Yi Sunbong, who had stealthily dug up the front segment of her father-in-law's gravesite and buried his own relative's body there. The first magistrate issued an order to exhume the body and bury it elsewhere. However, Yi deliberately delayed carrying out the order by providing endless excuses. Chŏng's husband was aggrieved by the situation and ultimately became ill. Chŏng narrated her grievance, stating:

Under such circumstances, how could I sustain my life to tragically live alone? I planned to grab a hoe and go to Yi Sunbong's gravesite to dig up the body and kill myself afterward. My husband will then recover from this and my mother-in-law will also be able to preserve her life. This is my wish. I bow and implore Your Honor to redress my grievance. I beg a thousand and ten thousand times and hope Your Honor will settle this case. (Komunsŏ 16:200-201)

The magistrate gave an order to investigate Yiss crime and to bring a drawing of the two gravesites. The magistrate commanded that if Yis trespassing of the burial site was explicit, he should be arrested. Although the petition does not provide further information, it seems Yi was directed to exhume the body according to Chŏng's ensuing petition.

In the eleventh month of that same year, Chŏng appealed again because Yi had failed to follow the order. She traveled to Kŭmsan and sojourned there for about twenty days waiting to directly petition the magistrate, who was out of town. When he returned, she pleaded to him once again about her situation. After reviewing the petition, the

\footnotetext{
${ }^{27}$ The date of the petition is unknown except that it was submitted in the year sinhae, which could be 1731, 1791, or 1851, depending on the sixty-year cycle in which the year fell. The private documents, including petitions, in the Komunsŏ 古文書 (Old documents) volumes compiled by the Kyujanggak Archive of Seoul National University and the Academy of Korean Studies are mostly from the late Chosŏn period.
} 
magistrate commanded that Yi be punished with beating, and this time he specifically stipulated a date by which to exhume the body (Komunsŏ 18:438-39).

Despite the magistrate's command, Yi continued to shrink from the exhumation. Chŏng had no choice but to visit Kŭmsan for the third time in the eighth month of the year ŭlmyo 乙卯. ${ }^{28}$ However, the magistrate was suddenly reassigned to a post in Taegu and was replaced by a new one. Chŏng reiterated to the new magistrate what had been previously addressed and entreated that her grievance be redressed. She stated:

I feel that even if I use my ten fingers to dig the ground, this [conflict] will end only when the body has been moved. I bow and plead to Your Honor to examine the documents of this case in detail and sympathize with my grievance. Please urge [Yi] to exhume [the body] by a designated date so that my husband and I, whose lives are about to cease, can sustain our lives. I beg a thousand and ten thousand times with my tears of blood and hope that Your Honor will settle this case. (Komunsŏ 18:439-40)

The magistrate ordered that Yi be arrested and interrogated as to why he was not exhuming the body even though he had lost the litigation. He commanded Yi to exhume it by the tenth day of the tenth month (Komunso 18:439-40). As Yi failed to execute this new order, Chŏng desperately petitioned the magistrate again in the same month. She stated that when her husband heard of the magistrate's command, there was hope for him to recover. However, his joy lasted only momentarily, as Yi again neglected the order. The magistrate, like his predecessors, commanded that Yi be vigorously pressed and arrested (Komunsŏ 18:440-41).

In Chŏng’s case, Yi had continuously put off digging up the body by appropriating a loophole in the law. In principle, only the person who had buried the body was permitted to exhume it, and those who arbitrarily dug without authorization were exiled. Even the county office was not allowed to order compulsory exhumation unless the case was considered particularly extreme (Kim Kyŏng-suk 2002, 75-83). Thus, if Yi risked being punished to protect the gravesite zone, it was difficult to arbitrate the case since Chŏng would have been punished for exhuming the body.

The outcome of Chŏng's case remains unknown, besides the fact that Yi was ordered to move the body. Nevertheless, the significance of Chŏng's petitions lies in her effort to appeal several times to the county office, which was far away from her residence, in order to reclaim the gravesite of her father-in-law, even though her husband was alive and technically should have done the petitioning.

Because marriage did not affect women's right to petition, wives often represented husbands when the husbands themselves were incapable of appearing at court. When women did appear to petition on family concerns as wives, their narratives were constructed to show that they appealed for the sake of their husbands' well-being, which would ultimately aid the entire family. Such a narrative complemented women in representing female virtues and made it seem as though they were complying with gender norms without defying patriarchal authority.

${ }^{28}$ The year ŭlmyo could refer to 1735,1795 , or 1855 . 
Women also utilized a narrative of pity and evoked the female gender when addressing grievances to convey that the degree of grievance or the sense of being wronged was felt much greater by widows, wives, and mothers than by male subjects. However, this does not necessarily mean that such a narrative only implied female weakness. For instance, Chŏng stressed her pain as a wife by elaborating on how she was undergoing hardships due to her husband's illness and how it was beyond her capacity as a woman to resolve the conflict. However, she concurrently characterized herself as a strong agent who was ready to assume a patriarchal role for the sake of the family. She conveyed her firm determination by stating that she even planned to grab a hoe and exhume the body, then kill herself afterward. Because her husband failed to psychologically overcome his grief, Chŏng undertook responsibility on the part of the entire family and confronted Yi herself. While her husband easily became incapable when faced with the dispute, she traveled at least five times to Kŭmsan to reclaim the gravesite of her father-in-law, which reflects the vulnerability of the husband's authority. By using a narrative that intricately entwined both femininity and masculinity, Chŏng was gendering herself but simultaneously reconstructing gender. Conversely, she was redefining norms of womanhood by representing both femininity and masculinity through executing legal roles of the domestic patriarch.

In both the mid and late Chosonn, the narrative used in women's petitions relied on the Confucian language that was expected by the state when entering the legal realm, but concurrently their narratives were constructed in a way that best suited their interests depending on their position within the household. Although women's lived experiences varied according to their different social statuses, linguistic practices were unified across status boundaries through the Confucian language of female virtue. Being able to use such language did not necessarily mean every female subject lived according to the prescriptive norms. However, by using the conventional form of speech, women voiced their concerns to seek their interests and did not remain silent.

\section{Conclusion}

In the juridical domain of the Chosŏn, gender and status hierarchies remained neutral in terms of a subject's legal capacity; this means that even female slaves were allowed to bring suits against male aristocrats. Since the state upheld neo-Confucianism as its sole ideology and reorganized society according to patriarchal, patrilineal, primogeniture, and gender systems that conflicted with some of the indigenous practices, the juridical domain was used as a space to contest and negotiate grievances that generated from the new systems. At the level of official representation, the state clearly attempted to impose a uniform vision of gender order based on Confucian norms. However, the state's creation of new policies to enforce gender order was fraught with contradictions. Although the state enforced female subjects to internalize Confucian gender norms, it was also the state that provided leeway for women to voice their concerns stemming from the same Confucian gender system. Furthermore, by appropriating their legal capacity, women exercised agency through the use of vernacular Korean, which eventually penetrated the literary space dominated by classical Chinese in the public realm. 
By carrying Confucian gender ethics enforced in domestic space to the legal space, the cultural conventions about gender norms and hierarchy were reinforced through their linguistic practices despite the fact that women and men were equally recognized as legal subjects. What female subjects gained from addressing personal grievances were a sense of personhood constructed around the Confucian patriarchal system. Appealing to redress grievances at times reinforced the gender hierarchy but at other times enabled women to challenge domestic patriarchy that manifested in a powerful form of female agency. For those who were wronged, petitioning was a measure of selfassertion and self-construction. Their agency was represented through the performance of petitioning when women were legally violated as moral individuals.

By capitalizing on the legal capacity to petition, legal subjects engaged in dialogue with the authorities, which enabled them to make a profound assertion of personhood by employing various narrative strategies. Through articulating the narrative of grievance, women in particular struggled to defend their own sense of morality. Furthermore, they represented their grievance through utilizing the narrative of pity underlining their weakness, vulnerability, and subordinate position within the society but at the same time boldly demanded that the state had a mandate to redress their grievance. Conversely, while cultural conventions about gender norms were reinforced in the judicial domain through their discourse of domesticity, women as legal subjects exercised agency by actively appropriating the petition system through using vernacular Korean and the narrative of Confucian female virtue to seek their interests.

\section{Acknowledgments}

This paper was partly written with the support of the Korea Foundation Field Research Fellowship and the Sigur Center Summer Faculty Research Award, George Washington University. I would like to acknowledge those who read the draft and provided generous comments at various stages of writing this article: Charles Kim, Kyoim Yun, Hilary Finchum-Sung, Jungwon Kim, Andrew Yeo, Taehyun Nam, and Susan L. Burns. I would also like to thank one anonymous reviewer for giving insightful comments. An earlier version of this paper was read at the Berkshire Conference of Women Historians, Toronto, May 22-25, 2014.

\section{List of References}

\section{Primary Sources}

Chungjong silloK 中宗實錄 [Veritable Records of King Chungjong]. 1970. In Chosŏn wangjo sillok [Veritable records of the kings of the Chosonn dynasty]. 48 vols. Seoul: Kuksa p’yŏnch'an wiwŏnhoe.

ILSǑNGNOK 日省錄 [RECORDS OF DAILY REFLECTIONS]. 1992. Edited by Kyujanggak Institute of Seoul National University. Seoul: Kyujanggak Institute of Seoul National University.

Komunsŏ 古文書 [Old Documents]. Compiled by Kyujanggak Institute of Seoul National University. Vols. 16-26. 
KOMUNSŎ CHIPSǑNG 古文書 集成 [COMPILATION VOLUME OF THE OLD DOCUMENTS]. Compiled by Academy of Korean Studies. 80 vols.

KWANGHAEGUN-ILGI 光海君日記 [Daily RECORds of King Kwanghae-gun]. 1970. In Chosŏn wangjo sillok [Veritable records of the kings of the Chosonn dynasty]. 48 vols. Seoul: Kuksa p'yŏnch'an wiwŏnhoe.

KYǑNGGUK tAejŏN 經國大典 [Administrative Great Code]. 1978. Translated by Pŏpchech'ŏ. Seoul: Ilchisa.

SimNiRoK 審理錄 [RECORDS OF SIMNI (HEARINGS)]. 1998-. Translated by Minjok munhwa ch’ujinhoe. 6 vols. Seoul: Minjok munhwa ch’ujinhoe.

SoK taejŏn 續大典 [Continuation of the Great Code]. 1965. Seoul: Pŏpchech’ŏ.

SŬNGJǑNGWǑN ILGI 承政院日記 [DAily RECORD of the Royal SECRETARIAT]. 1961-. Seoul: Kuksa p'yŏnch'an wiwŏnhoe.

\section{Secondary Sources}

Allee, Mark. 1994. Law and Local Society in Late Imperial China: Northern Taiwan in the Nineteenth Century. Stanford, Calif.: Stanford University Press.

Blaine, Marcia Schmidt. 2002. "Women and the New Hampshire Provincial Government." In Petitions in Social History, ed. Lex Heerma van Voss, 57-77. Cambridge: Cambridge University Press.

Bourdieu, Pierre. 1994. Language and Symbolic Power. Cambridge, Mass.: Harvard University Press.

Butler, Judith. 1999. Gender Trouble: Feminism and the Subversion of Identity. New York: Routledge.

— . 2007. "Performative Acts and Gender Constitution: An Essay in Phenomenology and Feminist Theory." In The Performance Studies Reader, ed. Henry Bial, 18799. New York: Routledge.

CH'oe CHAE-sŏK. 1966. Han'guk kajok yŏn'gu [A study of the Korean family]. Seoul: Minjung sŏgwan.

СнŎN KYŎNG-MOK. 1996. “Chosŏn hugi sansong yŏn'gu: 18, 19 segi komunsŏ chungsim uro" [A study of gravesite lawsuits in the late Chosŏn based on old eighteenthand nineteenth-century documents]. PhD diss., University of North Chŏlla.

—. 1998. "Chosŏn hugi sansong ŭi han sarye" [A case study of late Chosŏn gravesite disputes]. Komunsŏ yŏn'gu 14:69-98.

CHǑNG CHI-YǑng. 2001. “Chosŏn hugi ŭi yǒsŏng hoju yŏn'gu” [A study of women householders in the late Chosŏn]. PhD diss., Soggang University.

Davis, Natalie Zemon. 1987. Fiction in the Archives: Pardon Tales and Their Tellers in Sixteenth-Century France. Stanford, Calif.: Stanford University Press.

Deuchler, Martina. 1988/1989. "Heaven Does Not Discriminate: A Study of Secondary Sons in Chosŏn Korea." Journal of Korean Studies 6:121-64.

— 1992. The Confucian Transformation of Korea: A Study of Society and Ideology. Cambridge, Mass.: Council on East Asian Studies, Harvard University, distributed by Harvard University Press.

Duncan, John. 2000. The Origins of the Chosŏn Dynasty. Seattle: University of Washington Press.

Haboush, JaHyun Kim. 1991. "The Confucianization of Korean Society.” In The East Asian Region: Confucian Heritage and Its Modern Adaptation, ed. Gilbert Rozman, 84-110. Princeton, N.J.: Princeton University Press. 
— 2002. "Gender and Politics of Language in Chosŏn Korea." In Rethinking Confucianism: Past and Present in China, Japan, Korea, and Vietnam, eds. Benjamin A. Elman, John B. Duncan, and Herman Ooms, 220-57. UCLA Asia Pacific Monograph Series. Los Angeles: UCLA Asia Institute.

Han SAnG-GWǒn. 1996. Chosŏn hugi sahoe wa sowŏn chedo: Sangŏn/kyŏkjaeng yŏn'gu [Late Chosŏn society and the petition system: A study of written and verbal petitions to the king]. Seoul: Ilchogak.

—. 2008. "Chosŏn sidae sosong kwa woejibu: 1560 nyŏn kyŏngjupu kyŏlsong iban punsǒk" [Litigation and scriveners during the Chosŏn: An analysis of Kyŏngju County's legal case in 1560]. Yŏksawa hyŏnsil 69:255-92.

HAN U-GǓN. 1956. “Sinmun'go ŭi sŏlch’i wa kŭ silchejŏk hyonŭng e taehayŏ” [The establishment of the petition drum and its effectiveness]. In Tugye Yi Pyŏngdo paksa hwangap kinyŏm nonch'ong [Festschrift in commemoration of the sixtieth birthday of Dr. Tugye Yi Pyŏngdo], 357-408. Seoul: Ilchogak.

Hirsch, Susan. 1998. Pronouncing and Persevering: Gender and the Discourses of Disputing in an African Islamic Court. Chicago: University of Chicago Press.

Hong ŬN-Jin. 1998. "Kurye munhwa Yussiga ŭi han'gŭl soji e taehayŏ” [Vernacular Korean petition of Kurye Yu clan]. Komunsŏ yŏn'gu 13:111-43.

Karasawa, Yasuhiko. 2007. "Between Oral and Written Cultures: Buddhist Monks in Qing Legal Plaints.” In Writing and Law in Late Imperial China: Crime, Conflict, and Judgment, eds. Robert E. Hegel and Katherine Carlitz, 64-80. Seattle: University of Washington Press.

KIM, Jisoo M. 2009. "Individual Petitions: Petitions by Women in the Chosŏn.” In Epistolary Korea: Letters in the Communicative Space of the Chosŏn, 1392-1910, ed. JaHyun Kim Haboush, 68-76. New York: Columbia University Press.

2010a. “Crossing the Boundary of Inner Quarters: Elite Women’s Petitioning Activity in Late Chosŏn Korea.” In Korean Studies Forum, ed. Hyuk-Rae Kim, 4:221-43. Seoul: Yonsei University Press.

— 2010b. "Voices Heard: Women’s Right to Petition in Late Chosŏn Korea." PhD diss., Columbia University.

2013. "Law and Emotion: Tension between Filiality and Fidelity in a Property Dispute of Early Chosŏn Korea." Tongbang hakji 162:203-39.

- Forthcoming. The Emotions of Justice: Gender, Status, and Legal Performance in Chosón Korea. Seattle: University of Washington Press.

Kim, Jungwon. 2007. "Negotiating Virtue and the Lives of Women in Late Chosŏn Korea." PhD diss., Harvard University.

—. 2014. "You Must Avenge on My Behalf": Widow Chastity and Honour in Nineteenth-Century Korea." Gender and History 26(1):128-46.

KIM KYŏNG-SUk. 2002. "Chosŏn hugi sansong kwa sahoe kaldŭng yŏn'gu” [A study of gravesite lawsuits in the late Chosŏn and social conflicts]. PhD diss., Seoul National University.

—. 2005. "Chosŏn hugi yŏsŏng ŭi chŏngso hwaldong” [Women’s petitioning activity in the Late Chosŏn]. Hankuk munhwa 36 (December):89-123.

KIM SŏN-KYŏNG. 1993. "Chosŏn hugi sansong kwa sanrim soyukwŏn ŭi silt’ae” [Gravesite lawsuits in the late Chosŏn and the ownership of mountains and forests]. Tongbang hakji 77-79:497-535.

KIM YonG-KYŏNG. 2001. "Pyŏnghae Hwang ssi ka Wansan Yi ssi ŭi yuŏn mit soji” [Will and petition of Madam Yi from the Pyŏnghae Hwang]. Munhŏn kwa haesŏk 14:76-77. 
Kim Young-min and Michael J. Pettid, eds. 2011. Women and Confucianism in Chosŏn Korea: New Perspectives. Albany: SUNY Press.

Kuehn, Thomas. 1991. Law, Family, and Women: Toward a Legal Anthropology of Renaissance Italy. Chicago: University of Chicago Press.

Macauley, Melissa. 1998. Social Power and Legal Culture: Litigation Masters in Late Imperial China. Stanford, Calif.: Stanford University Press.

Mark, Gregory A. 1998. "The Vestigial Constitution: The History and Signification of the Right to Petition." Fordham Law Review 66:2153-231.

Orchard, Christopher. 2002. "The Rhetoric of Corporeality and the Political Subject: Containing the Dissenting Female Body in Civil War England.” In Women as Sites of Culture: Women's Roles in Cultural Formation from the Renaissance to the Twentieth Century, ed. Susan Shifrin, 9-24. Burlington, Vt.: Ashgate.

PAK PYŏNG-Ho. 1974. Han'guk pŏpchesa go [Thoughts on Korean legal history]. Seoul: Pŏmmunsa.

. 1996. Kŭnse ǔi pŏp kwa pŏpsasang [Early modern law and legal thought]. Seoul: Chinwŏn.

Peterson, Mark A. 1996. Korean Adoption and Inheritance: Case Studies in the Creation of a Classic Confucian Society. Ithaca, N.Y.: Cornell University Press.

Tucker, Judith E. 2008. Women, Family, and Gender in Islamic Law. New York: Cambridge University Press.

YI Сно̆NG-OK. 1982. "Wansan Yi ssi yuŏn ko" [A study of Wansan Madam Yi's will]. Munhak kwa ŏno 3:165-67.

Zarinfraf-Shahr, Fariba. 1997. "Ottoman Women and the Tradition of Seeking Justice in the Eighteenth Century." In Women in the Ottoman Empire, ed. Madeline C. Zilfi, 253-63. New York: Brill. 